\title{
Reaction of 1, 3-Di-(1-piperidyl)-2-nitropropane with Thiophenol and Hydrogen Sulfide and Preparation of 5-Nitrohexahydropyrimidin-2-thione
}

E.M. Afsah, E.M. Keshk, M. Hammouda and M. E. Telip Chemistry Department, Faculty of Science, Mansoura University, Mansoura, Egypt.

\footnotetext{
T HE CHEMISTRY and biological activities of Mannich bases have received considerable interest. The alkylation of amines, active methylene compounds and thiols with Mannich bases has been the subject of extensive studies as the products are of considerable synthetic and pharmaceutical interest.
}

The synthetic potential of Mannich bases as alkylating agents formed the subject of extensive investigation by numerous workers ${ }^{(1-10)}$. The $S$-alkylation of thiols with ketonic Mannich bases has been investigated due to its pharmacological relevance $^{(1,7,11,12)}$. This reaction has been carried out using Mannich bases derived from ketones, phenols and indoles ${ }^{(7,11-15)}$, whereas there are no literature reports on the use of Mannich bases derived from nitroalkanes in such reactions.

In the present study, we investigated the $S$-alkylation of thiols with the nitro bis-base (1), and some interesting results were obtained in this direction. Thus, 1,3-di-(1-piperidyl)-2-nitropropane (1) was prepared according to an earlier report $^{(16,17)}$. The $S$-alkylation of thiophenol with 1 proceeded in high yield, under mild conditions to give 1,3-di(phenylsulfanyl)-2-nitropropane (2). Obviously, compound 2 was formed by a mechanism which involves the elimination-addition sequence, via 2-nitro-1-alkene intermediates of the type 3 and 5, which are formed through two successive deamination reactions of 1 and 4 , probably with participation of the aci-forms 1' and 4', respectively (Scheme 1). This rationale received support from the fact that 2-nitro-1-alkenes are prepared by deamination of nitro Mannich bases ${ }^{(17)}$. The IR spectrum of 2 showed bands at 1545, $1375 \mathrm{~cm}^{-1}$ $\left(\mathrm{NO}_{2}\right)$. Compound 2 had previously been prepared by Barton et al. ${ }^{(18)}$ by treating 2 nitro-1,3-propanediol dipivalate with thiophenol in presence of triethylamine. 


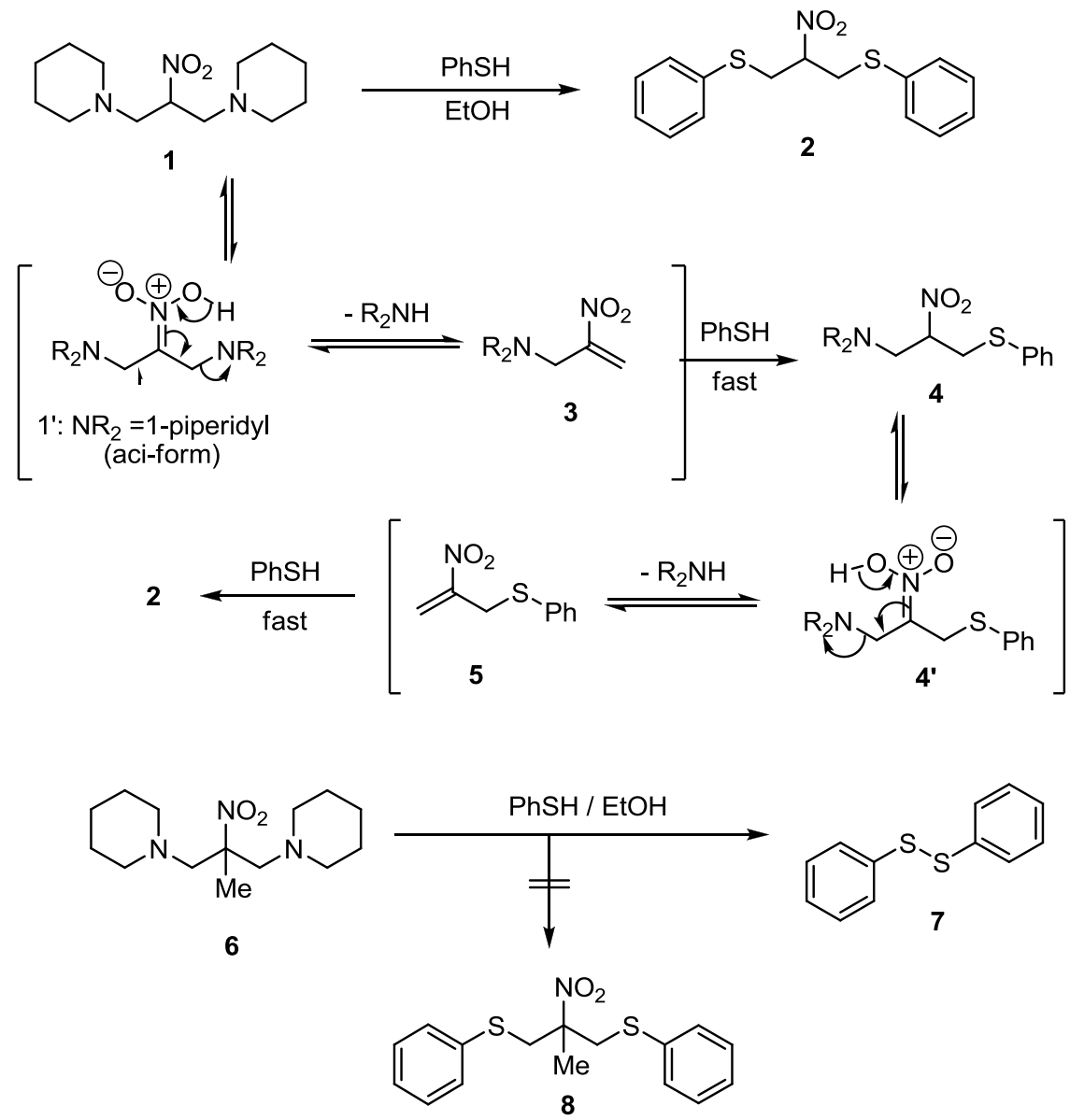

Scheme 1

On the other hand, treatment of 2-methyl-2-nitro-1,3-bis(1-piperidyl)propane $(6)^{(17)}$, with thiophenol lead to the formation of diphenyl disulphide (7) in a poor yield, rather than in the formation of the expected compound 8 . The IR spectrum of 7 showed bands at $735,682 \mathrm{~cm}^{-1}$ (mono substituted benzene ring). The mass spectrum of 7 revealed $\mathrm{M}^{+}$at $\mathrm{m} / \mathrm{z} 218$, the base peak at $\mathrm{m} / \mathrm{z} 65(100 \%)$ is due to $[(\mathrm{S}-\mathrm{S})+\mathrm{H}]$ fragment, and the $\mathrm{M}^{+} / 2$ ion at $\mathrm{m} / \mathrm{z} 109[\mathrm{PhS}]^{+}$.

In view of the reported formation of bis- $\left(\beta\right.$-acylethyl)sulphides $\left(\mathrm{ArCOCH}_{2} \mathrm{CH}_{2}\right)_{2} \mathrm{~S}$, by treating ketonic Mannich bases with thioacetamide ${ }^{(15)}$, it was expected that the dinitro-sulphide derivative (9) or 3,7-dinitro-1,5-dithiacyclooctane (10), might be obtained by a similar reaction from 1 . However, treatment of 1 with thioacetamide afforded a product which was identified on the bases of its Egypt. J. Chem. 54, No. 6 (2011) 
analytical and spectral data as 6-nitro-7-(1-piperidyl)-1,2,4-trithiaheptane (11) (Scheme 2). The analytical and mass spectral data of 11 were consistent with the molecular formula $\mathrm{C}_{9} \mathrm{H}_{18} \mathrm{~N}_{2} \mathrm{O}_{2} \mathrm{~S}_{3}$. The IR spectrum showed two strong bands at 1546 and $1361 \mathrm{~cm}^{-1}\left(\mathrm{NO}_{2}\right)$. The ${ }^{1} \mathrm{H}$ NMR spectrum of $11\left(\mathrm{CDCl}_{3}\right)$ revealed bands at $\delta$ 1.69-1.72 $(6 \mathrm{H}, \mathrm{m}, 1$-piperidyl $\beta, \gamma-\mathrm{H}), 2.17(4 \mathrm{H}, \mathrm{m}, 1$-piperidyl $\alpha-\mathrm{H}), 2.80$ $3.15\left(4 \mathrm{H}, \mathrm{m}, \mathrm{CH}_{2}-\mathrm{N}\right.$ and $\left.\mathrm{CH}_{2}-\mathrm{S}\right), 3.50\left(2 \mathrm{H}, \mathrm{s}, \mathrm{S}-\mathrm{CH}_{2}-\mathrm{S}\right), 4.00\left(1 \mathrm{H}, \mathrm{m}, \mathrm{CH}-\mathrm{NO}_{2}\right)$. Its mass spectrum underwent fragmentation pattern which supported its structure (Scheme 3). The base peak at $\mathrm{m} / \mathrm{z} 84(100 \%)$ is due to the 1-piperidyl fragment. The fragments at $\mathrm{m} / \mathrm{z} 125,111,79,65$ and 64 are consistent with the presence of the $\left(\mathrm{CH}_{2}-\mathrm{S}-\mathrm{CH}_{2}-\mathrm{S}-\mathrm{S}-\mathrm{H}\right)$ moiety. A very intense ion at $\mathrm{m} / \mathrm{z} 56$ is found in the spectrum, which is probably due to fragmentation of the 1-piperidylmethyl ion $\mathrm{m} / \mathrm{z} 98$.

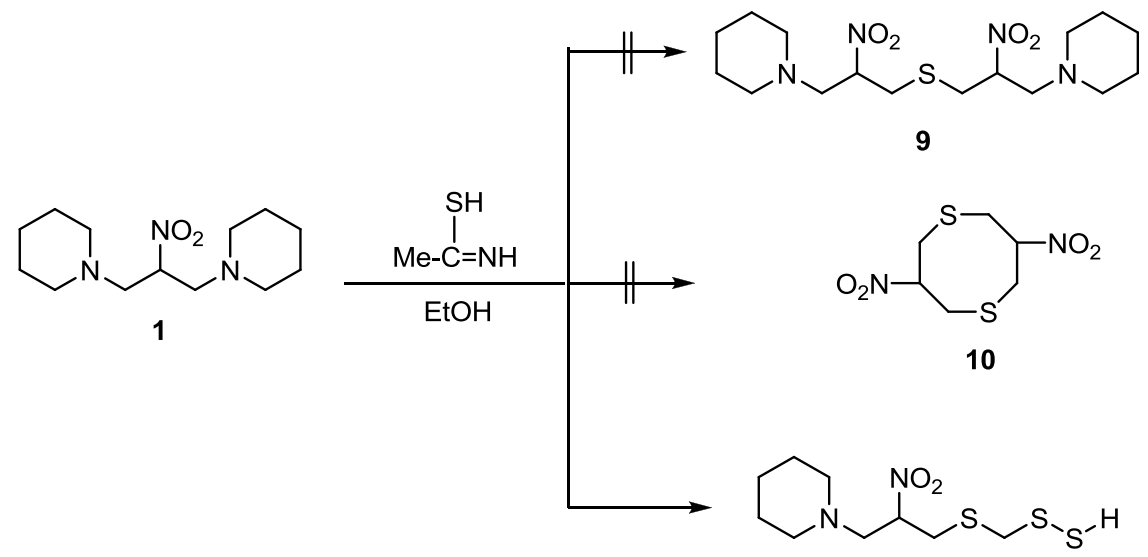

11

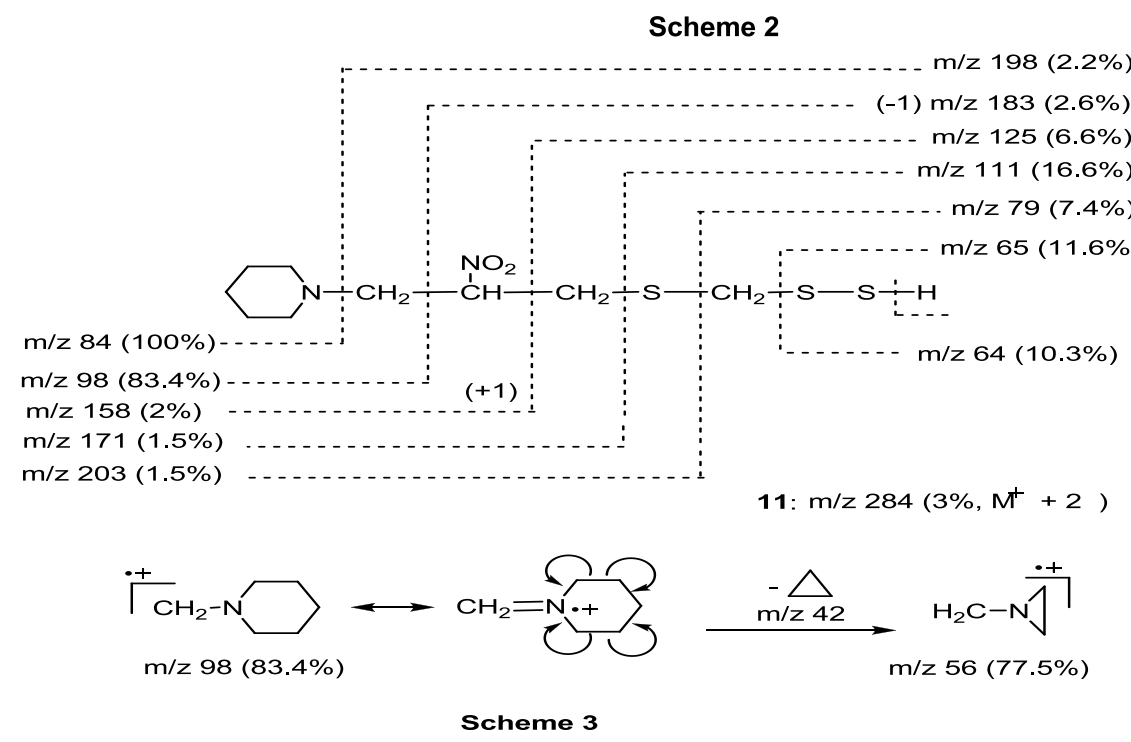

Egypt. J. Chem. 54, No. 6 (2011) 
The formation of 11 is believed to proceed via the intermediacy of 3 , which adds hydrogen sulphide to give 12 . The reaction between 12 and 13 may lead to the S-Mannich base 14, which reacts further with thioacetamide to afford 11 (Scheme 4). The formation of an intermediate of the type 14 from 12 and 13 via transaminomethylation is reasonable, since the transaminomethylation reaction of Mannich bases has been reported ${ }^{(1,3)}$ and this reaction has some relevance in organic synthesis ${ }^{(19)}$. This reaction involves deaminomethylation of the Mannich base 1 to afford 13, the deaminomethylation of nitro-Mannich bases has been reported $^{(20-22)}$.

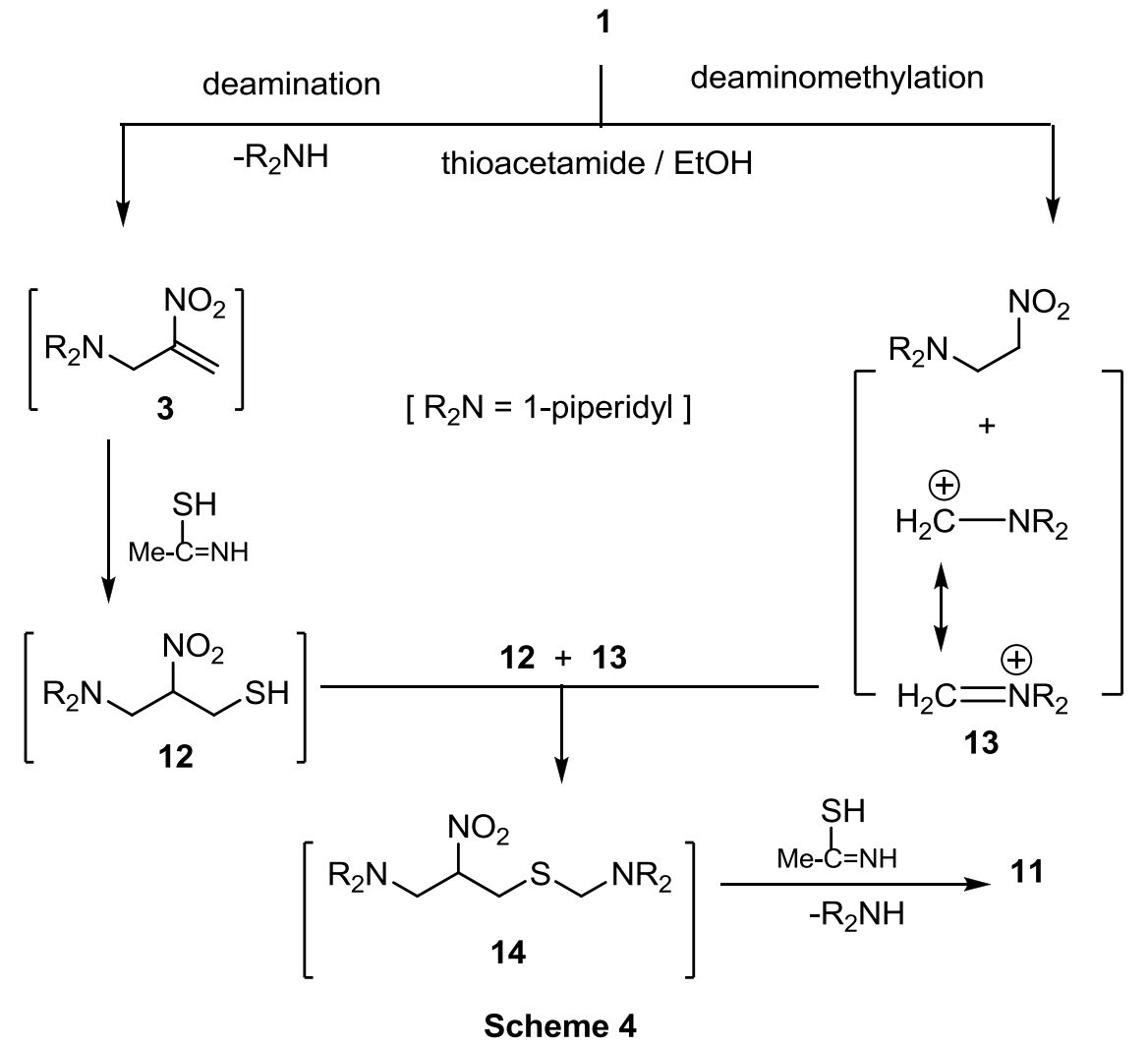

In the course of this study, we synthesized 1,2,3,4,5,6-hexahydro-5-nitro-2thioxopyrimidine (15), by treating thiourea with nitromethane and formaldehyde in presence of triethylamine. Attempts have also been made to prepare the heterobicyclic system 16 by using the same reactants in a molar ratio $1: 2: 4$, but the only product obtained was the N-hydroxymethyl derivative 17 (Scheme 5). The structure of compounds 15 and 17 was supported by analytical and spectral data. The IR spectrum of 15 showed bands at $3388 \mathrm{~cm}^{-1}(\mathrm{NH}), 1552,1352 \mathrm{~cm}^{-1}$ $\left(\mathrm{NO}_{2}\right), 1188 \mathrm{~cm}^{-1}(\mathrm{C}=\mathrm{S})$. The IR spectrum of 17 revealed a broad band at 3300-

Egypt. J. Chem. 54, No. 6 (2011) 
$3400 \mathrm{~cm}^{-1}$ (NH and $\left.\mathrm{OH}\right), 1553,1351 \mathrm{~cm}^{-1}\left(\mathrm{NO}_{2}\right), 1194 \mathrm{~cm}^{-1}(\mathrm{C}=\mathrm{S})$. The mass spectrum of 17 showed $\mathrm{M}^{+}$at $\mathrm{m} / \mathrm{z} 191$.

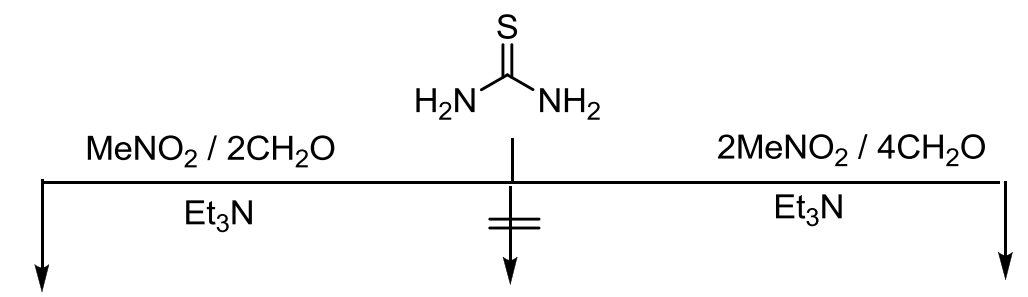<smiles>O=[N+]([O-])C1CNC(=S)NC1</smiles>

15<smiles>O=[N+]([O-])C1CN2CC([N+](=O)[O-])CN(C1)C2=S</smiles>

16

Scheme 5

\section{Experimental}

All melting points are uncorrected. Elemental analyses were carried out in the Microanalytical Unit, Faculty of Science, Cairo University. The infrared spectra were recorded on a Mattson 5000 FTIR spectrometer. ${ }^{1} \mathrm{H}$ NMR data were taken on a Varian XL $200 \mathrm{MHz}$ instrument using TMS as an internal standard with $(\delta=0 \mathrm{ppm})$. The mass spectra were determined on a Shimadzu GC-MS QP -1000 EX instrument. Compounds 1 and 6 were prepared as previously described ${ }^{(16,17)}$.

\section{1,3-Di(phenysulfanyl)-2-nitropropane (2)}

A mixture of $1(1 \mathrm{mmol})$ and thiophenol $(2 \mathrm{mmol})$ in ethanol $(15 \mathrm{ml})$ was refluxed for $2 \mathrm{hr}$, and allowed to stand at room temperature for $48 \mathrm{hr}$. The precipitated product was filtered off, dried and crystallized from ethanol to give 2 ; yield $82 \%$, m.p. $38-40{ }^{\circ} \mathrm{C}$. [Lit. ${ }^{18}$, m.p. $38^{\circ} \mathrm{C}$ ].

6-Nitro-7-(1-piperidyl)-1,2,4-trithiaheptane (11)

A mixture of $1(1 \mathrm{mmol})$ and thioacetamide $(1.5 \mathrm{mmol})$ in ethanol $(15 \mathrm{ml})$ was refluxed for $2 \mathrm{hr}$, and allowed to stand at room temperature for $48 \mathrm{hr}$, then diluted with water. The precipitated product was filtered off, dried, and crystallized from ethanol to give 11 ; yield $70 \%$, m.p. $95{ }^{\circ} \mathrm{C}$.

Analysis $\quad \mathrm{C}_{9} \mathrm{H}_{18} \mathrm{~N}_{2} \mathrm{O}_{2} \mathrm{~S}_{3}$ (M. Wt.: 282.45)

Requires $\quad \mathrm{C}, 38.27 ; \mathrm{H}, 6.42 ; \quad \mathrm{N}, 9.92$

Found $\quad \mathrm{C}, 38.30 ; \mathrm{H}, 6.51 ; \mathrm{N}, 10.00 \%$ 


\section{1,2,3,4,5,6-Hexahydro-5-nitro-2-thioxopyrimidine (15)}

A mixture of nitromethane $(50 \mathrm{mmol})$ and formalin $(100 \mathrm{mmol})$ in ethanol $(25 \mathrm{ml})$ was refluxed for $1 \mathrm{hr}$, then thiourea $(50 \mathrm{mmol})$ and two drops of triethylamine were added. The reaction mixture was refluxed for $0.5 \mathrm{hr}$ and left to cool. The product was collected by filtration, dried and crystallized from ethanol-benzene (2:1) to give 15 ; yield $74 \%$, m.p. $155^{\circ} \mathrm{C}$.

Analysis $\quad \mathrm{C}_{4} \mathrm{H}_{7} \mathrm{~N}_{3} \mathrm{O}_{2} \mathrm{~S}(\mathrm{M}$. Wt.: 161.18)

Requires $\quad \mathrm{C}, 29.81 ; \mathrm{H}, 4.38 ; \mathrm{N}, 26.07$

Found: $\quad$ C, $29.99 ; \quad \mathrm{H}, 4.66 ; \mathrm{N}, 25.95 \%$

N-Hydroxymethyl-1,2,3,4,5,6-hexahydro-5-nitro-2-thioxopyrimidine (17)

A mixture of nitromethane $(50 \mathrm{mmol})$ and formalin $(100 \mathrm{mmol})$ in ethanol $(25 \mathrm{ml})$ was refluxed for $1 \mathrm{hr}$, then thiourea $(25 \mathrm{mmol})$ and two drops of triethylamine were added. The reaction mixture was refluxed for $0.5 \mathrm{hr}$ and left to cool. The product was collected by filtration, dried and crystallized from ethanol-benzene $(2: 1)$ to give 17 ; yield $60 \%$, m.p. $250{ }^{\circ} \mathrm{C}$.

Analysis $\mathrm{C}_{5} \mathrm{H}_{9} \mathrm{~N}_{3} \mathrm{O}_{3} \mathrm{~S}$ (M. Wt.: 191.21)

Requires C, 31.41; H, 4.74; N, 21.98

Found $\quad$ C, 31.28; H, 4.63; N, 21.79\%

\section{References}

1. Tramontini, M., Synthesis, 703 (1973).

2. Tramontini, M. and Angiolini, L., Tetrahedron, 46, 179 (1990).

3. Craig, J. C., Moyle, M. and Johnson, L. F., J. Org. Chem. 29, 410 (1964).

4. Craig, J. C., Johns, S. R. and Moyle, M., J. Org. Chem. 28, 2779 (1963).

5.Afsah, E.M., Hammouda , M., Khalifa, M. M. and Al-Shahaby , E. H., Z. Naturforsch. 63b, 577 (2008).

6. Hammouda, M., Hamama, W. S., Kandeel, E.M. and Afsah, E. M., Pharmazie, 43, 529 (1988)

7. Afsah, E.M., Kandeel, E.M., Khalifa, M.M. and Hammouda, W.M., Z. Naturforsch. 62b, 540 (2007).

8. Roman, G., Comanita, E. and Comanita, B., Acta Chim. Slov. 49, 575 (2002).

9.Roman, G., Comanita, E. and Comanita, B., Chem. Heterocycl. Comp. 38, 1072 (2002).

10.Soldatenkov, A.T., Kutyakov, S.V., Volkov, S.V., Mamyrbekova, Zh. A. and Polyanski, B., Chem. Heterocycl. Comp. 40, 1499 (2004).

Egypt. J. Chem. 54, No. 6 (2011) 
11. Andrisano, R., Angeloni, A.S. and Tramontini, M., Ann. Chim. (Rome), 55, 1093 (1965); Chem. Abstr. 64, 11117h (1966).

12. Angeloni, A. S., Angeloni, L., De Maria, P. and Fini, A., J. Chem. Soc. [C], 2295 (1968).

13. Uher, M. and Toma, S., Collect. Czech. Chem. Commun. 36, 3056 (1971).

14. Andrisano, R., Angeloni, A. S., De Maria, P. and Tramontini, M., J. Chem. Soc. [C], 2307 (1967).

15. Gill, N. S., James, K. B., Lions, F. and Potts, K. T., J. Amer. Chem. Soc. 74, 4923 (1952).

16. Lambert, A. and Rose, J. D., J. Chem. Soc. 1511 (1947).

17. Blomquist, A. T. and Shelley, T. H., J. Amer. Chem. Soc. 70, 147 (1948).

18. Barton, D. H. R., Togo, H. and Zard, S., Tetrahedron, 41, 5507 (1985).

19. Buchanan, G. L. and Curran, A. C. W., Chem. Commun. 773 (1966).

20. Belikov, V.M., Belokon, Y.N., Dolgaya, M. M. and Martinkova, N.S., Tetrahedron, 26, 1199 (1970).

21. Belikov, V. M., Belokon, Y. N., Dolgaya, M. M. and Martinkova, N. S., Izv. Akad. Nauk. SSSR, Ser. Kim. 471, 1721, 2234 (1967); Chem. Abstr., 67, 32226 (1967); 68, 12228,86632 (1968).

22. Dolgaya, M. M., Belokon, Y. N. and Belikov, V. M., Izv. Akad. Nauk. SSSR, Ser. Kim. 74 (1969); Chem. Abstr. 70, 114397 (1969).

(Received 27/12/2010; accepted 11/7/2012 ) 


$$
\begin{aligned}
& \text { تفاعل 1,3-ثنائى (1- ببريديل) - 2-نتروبرويان مع الثيوفينول }
\end{aligned}
$$

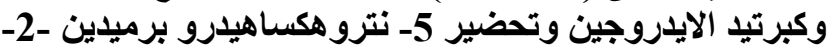

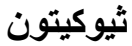

$$
\begin{aligned}
& \text { السيا محمد عفصة ، إيمان محمد كثثك ، متولى حموده و مرضية طلب } \\
& \text { قسم الكيمياء - كلية العلوم - جامعة المنصورة - المنصورة دمثر مصر. }
\end{aligned}
$$

تعتبر "قو اعد مانيش" ذات أهمية كبيرة من الناحيتين الكيميائية والبيولوجية وتدخل

هذه القواعد فى عمليات ادخال مجموعة الألكيل فى الأمينات ومركبات المين المثيلين

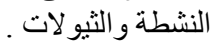

